\title{
Alisma plantago-aquatica L.: the cytoskeleton of the suspensor development
}

\author{
Joanna Świerczyńska*, Jerzy Bohdanowicz \\ Department of Plant Cytology and Embryology, University of Gdańsk, Wita Stwosza 59, 80-308 Gdańsk, Poland
}

\begin{abstract}
The actin and the tubulin cytoskeleton organization during the differentiation of the embryo-suspensor in Alisma plantago-aquatica was studied in comparison with the development of embryo, using immunofluorescence detection and rhodamine-phalloidin assay. At the early stage of the suspensor basal cell development (from 2- to 10-celled embryos) microfilaments form an abundant network in the cytoplasm of the basal cell, while the microtubules form a delicate network. At the mature stage of development (from a dozen to several dozen-celled embryos), in the suspensor basal cell, the microfilaments and microtubules were localized from micropylar to chalazal pole of the cell. At the micropylar end of the basal cell a high amount of actin and tubulin material was observed. The microfilaments were mainly arranged parallel whereas numerous bundles of microtubules distributed longitudinally or transversally to the long axis of the cell. At this stage of basal cell functioning, some bundles of microtubules appeared to pass close to the nucleus surface. Microtubules were also observed distributed at the chalazal pole of the basal cell. At the senescence stage of the suspensor basal cell (>100-celled embryos) the actin and tubulin filaments disorganize, some disrupted microfilaments and microtubules were observed in the cytoplasm of the basal cell. At all stages of the suspensor basal cell development in the embryo cells an extensive actin and tubulin network was observed.
\end{abstract}

Keywords: microfilaments; microtubules; immunofluorescence; Alisma plantago-aquatica; embryo-suspensor

\section{Introduction}

Embryogenesis is an important and complex period during the early stages of flowering plants development. The embryo of many species is differentiated into two parts: embryo-suspensor and embryo-proper. Suspensor is a terminally differentiated, short-lasted organ that keeps the embryo inside the embryo sac [1]. Numerous studies upon cytochemistry [2,3], ultrastructure [4], and synthetic activity $[5,6]$ confirm that suspensor is involved in the absorption, synthesis, and movement of nutrients from surrounding tissues into the embryo, thereby enabling a proper course of the embryo differentiation $[7,8]$. In addition, the role of suspensor in transport of nutrients to the embryo is also confirmed by ultrastructure of the organ, especially development of walls typical for so-called transfer cells that are specialized in short-distance, active movement of substances by plasmalemma $[9,10]$. Presence of walls of the transfer character was described, among others, for suspensor in Phaseolus [4], or Alisma [2]. A few literature data on the cytoskeleton during formation, development, and differentiation of polyploid

\footnotetext{
* Corresponding author. Email: joanna.swierczynska@biol.ug.edu.pl
}

Handling Editor: Elżbieta Bednarska-Kozakiewicz cells of embryo-suspensor have been reported [11]. During the karyological differentiation, polyploidization occurs in suspensor cells [12]. Endoreduplication is the most common polyploidization mechanism within the suspensor, which consists in cyclically repeating DNA synthesis - with no mitosis - which leads to multiplied ploidy level in suspensor cells [13]. At many plant species, endoreduplication leads to the high ploidy level during suspensor differentiation, e.g. 8192C in Phaseolus coccineus [14], 4096n in Phaseolus hysterinus and 2048C in Tropaeolum majus [15], and 1024n in Alisma plantago-aquatica [16]. It seems that polyploidization is widespread in seed plants and is especially prevalent in tissues of a secretory and trophic character [12]. On the other hand, up-to-date observations of actin and tubulin cytoskeleton organization during differentiation of highly polyploid suspensor cells, are limited to a few species such as Gagea lutea [17,18], Sedum acre [11], or Phaseolus coccineus [19]. In our previous preliminary studies in Alisma plantagoaquatica extremely abundant cytoskeleton in suspensor cells was recorded. The A. plantago-aquatica suspensor, in particular its basal cell, appears to be a convenient object to study the changes in the organization of cytoskeleton during differentiation of endopolyploid cells.

The aim of this study was to analyze changes in the organization of actin and tubulin skeleton during the suspensor 
basal cell differentiation in Alisma plantago-aquatica in comparison with the development of embryo-proper using immunofluorescence and rhodamine-phalloidin assay.

\section{Material and methods}

\section{Plant materials}

Plants of Alisma plantago-aquatica were obtained from natural habitats of Lipce near Gdańsk in northern Poland. Flowers in various developmental stages were collected in summer months (July and August).

\section{Fluorescence assay of F-Actin}

The ovules were isolated from ovaries and incubated for 15-60 min in 400- $\mu \mathrm{M}$ m-maleimidobenzoic acid $\mathrm{N}$ hydroxysucinimide ester $[20,21]$ in piperazine buffer containing 5\% dimethyl sulfoxide (DMSO) to permeate the cells [22]. After that the ovules were fixed in $4 \%$ formaldehyde freshly prepared from paraformaldehyde in piperazine buffer containing 5\% DMSO for $4 \mathrm{~h}$ at room temperature. The ovules were washed in piperazine buffer and stained with $0.33 \mu \mathrm{M}$ rhodamine-phalloidin in piperazine buffer containing 5\% DMSO for $1.5 \mathrm{~h}$. Next, after several washes in piperazine buffer, the suspensor and embryo proper were isolated manually from ovules under a stereoscopic microscope and placed on a microscope slide.

\section{Immunolocalization of microfilaments and microtubules}

To localize of microfilaments, ovules were fixed as described above and then treated according to the procedure [23]. For the localization of microtubules, ovules were fixed in $4 \%$ formaldehyde (freshly prepared from paraformaldehyde) and $0.25 \%$ glutaraldehyde in piperazine buffer for $4 \mathrm{~h}$ at room temperature. Then the ovules were prepared using the procedure described previously [24]. Next, after several washes in piperazine buffer, they were dehydrated in an ethanol series, each containing $10 \mathrm{mM}$ dithiothreitol [25] to minimize background of the cytoplasm. Then, the plant material was embedded with Steedman's wax [26]. The $5 \mu \mathrm{m}$ thick sections were made and placed on microscope slides coated with Mayer's egg albumen. The sections were dried overnight, dewaxed in ethanol, re-hydrated in an ethanol-PBS series and rinsed in PBS. Tissue samples were pre-incubated in PBS containing $0.1 \%$ bovine serum albumin for $45 \mathrm{~min}$ at room temperature. For the localization of microfilaments and microtubules slides were incubated overnight at $4^{\circ} \mathrm{C}$ with mouse anti-actin monoclonal antibody (clone C4, ICN; diluted 1:1000) and mouse anti- $\beta$-tubulin monoclonal antibody (Amersham N357, diluted 1:200), accordingly. Then, the preparations were rinsed in PBS and incubated for $4 \mathrm{~h}$ in a secondary Alexa 488-conjugated antimouse (Molecular Probes; diluted 1:800) antibody. Sections were rinsed in PBS, nuclei stained by 4',6'-diamidino-2-phenylindole dihydrochloride (DAPI; $1 \mu \mathrm{g} / \mathrm{ml}$, Sigma). Next slides were treated with $0.01 \%$ toluidine blue to diminish the autofluorescence of cell walls and mounted in an antifading solution (Citifluor, Agar). In control experiments, conducted in a similar manner the primary antibody was omitted, no actin and tubulin staining was detected. Fluorescence was observed with a Nikon Eclipse E 800 epifluorescence microscope equipped with a CCD cooled camera.

\section{Results}

In Alisma plantago-aquatica, the first zygote division is transverse, larger basal cell and smaller apical cell is formed, that divides mitotically and initiates the embryo and chalazal suspensor. The basal cell does not divide further; instead it rapidly grows in size and functions as a suspensor basal cell. Nucleus of the basal cell undergoes endoreduplication and then it becomes polytene and reaches its maximum ploidy level $1024 \mathrm{n}$. Changes in the configuration of actin and tubulin cytoskeleton were observed during differentiation of the suspensor basal cell in A. plantago-aquatica as compared to the developmental stages of the embryo.

\section{The early stage of the suspensor basal cell \\ development (from 2- to 10-celled embryos)}

The two-celled embryo is differentiated into the large basal cell and a smaller apical cell. The basal cell occupies the micropylar end of the embryo sac. Oval, enlarged nucleus occupies a central place in the basal cell. A single, significantly expanded nucleolus is visible in the nucleus (Fig. 1a,b). At this stage of development, the actin skeleton has been examined both using antibodies (Fig. 1a) and rhodamine-phalloidin (Fig. 1b), and achieved results were comparable. The actin material revealed due to immunofluorescence technique is present in cytoplasm of the basal cell as a network of fine microfilaments (Fig. 1a). Bundles of microfilaments get denser at the micropylar end of the basal cell (Fig. 1b). In the apical cell, actin is visible as a few faint dots (Fig. 1a,b). After staining with rhodamine-phalloidin, bundles of microfilaments form a dense network filling the cytoplasm of the basal cell (Fig. 1c,d). Numerous of F-actin filaments are arranged in circles (Fig. 1c), while others are focused to form intensely fluorescent areas (Fig. 1d). Later in this stage of development, the suspensor basal cell significantly increases in size and the nucleus is also enlarged (Fig. 1e,f). The tubulin skeleton occurs as an irregular network of microtubules in the basal cell cytoplasm (Fig. 1e,f). Microtubules intensely fluoresce and take the form of cortical network in embryo-proper cells (Fig. 1e). Around embryo sac cavity a strong fluorescence of cutin is visible (Fig. 1e).

\section{The mature stage of the suspensor basal cell development (from a dozen to several dozen-celled embryos)}

At this development stage, the suspensor basal cell further grows in size, and its micropylar end is characteristically "elongated". The nucleus is enormous and moves toward the chalazal end of the basal cell (Fig. 2a). Actin filaments localized in the suspensor basal cell are mainly arranged along the micropylar-chalazal axis of the cell. Actin skeleton forms a dense network of microfilaments (Fig. 2a,b). At this stage of development, actin filaments are visible in large quantities at the micropylar end of a cell, where actin material forms denser arrangements. Actin material is also present in the vicinity of nuclear envelope, where it is visible as intensely fluorescent regions (Fig. 2a). The 

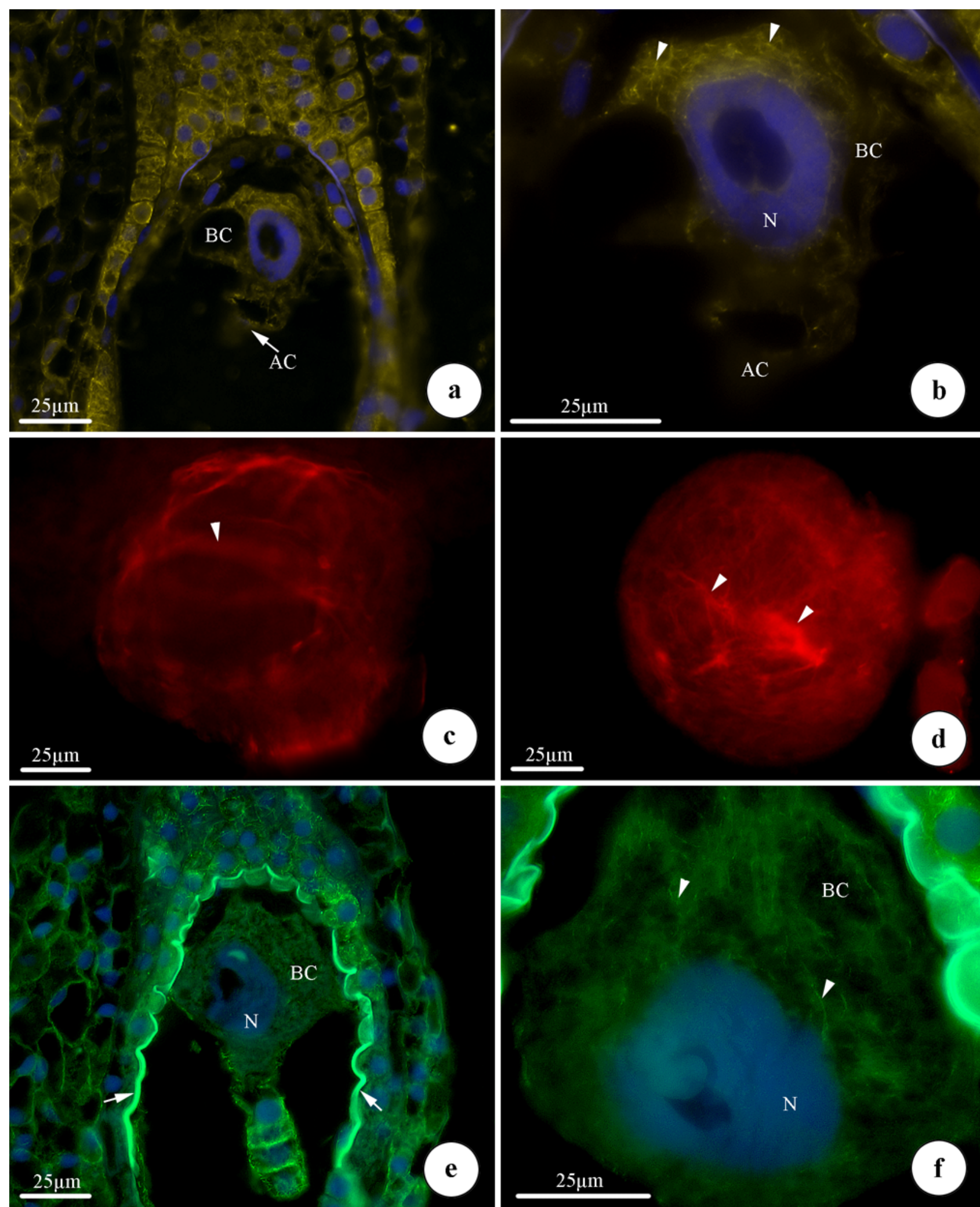

Fig. 1 The initial stage of the suspensor development of Alisma plantago-aquatica. a,b Images of immunofluorescence assay of microfilaments. a Two-celled embryo, visible basal cell and apical cell. b Microfilament network (arrows head) visible in the basal cell; enlarged nucleus and densities of actin filaments at the micropylar end of the cell. Few clusters of actin material in apical cell. c,d Images of F-actin visualized by rhodamine-phalloidin. $\mathbf{c}$ F-actin filaments form a dense network in the suspensor basal cell; numerous actin filaments are circularly arranged (arrow head). d Some microfilaments focus and form intensively fluorescent areas in the basal cell cytoplasm (arrows head). e,f Images of immunofluorescence assay of microtubules. e Five-celled embryo. Fine microtubule network visible in the basal cell cytoplasm and intensively fluorescent tubulin skeleton in embryo cells. A strong fluorescence of cutin around sac cavity is present (arrows). f Microtubule network (arrows head) in suspensor basal cell; changed basal cell shape and enlarging nucleus. AC - apical cell; BC - basal cell; $\mathrm{N}$ - nucleus. 
actin skeleton in embryo cells takes the form that is typical for normal somatic cells; the cortical, near-wall networks dominate (Fig. 2a,b). Elements of tubulin skeleton are the most abundantly arranged at the micropylar, transfer wall of the suspensor basal cell. Densities of tubulin material are also present near the huge, polytene basal cell nucleus (Fig. 2c). In older suspensor basal cells, microtubules are parallel to the long axis of the cell in the direct vicinity of a contact surface, yet arranged in different directions in the distal part of the wall ingrowths (Fig. 2d,e). Strongly fluorescent microtubules are present at the nucleus (Fig. 2c,e). At this development stage, concentrations of tubulin material can be seen at the chalazal end of a cell (Fig. 2d). Tubulin skeleton in embryo-proper cells takes the configurations typical for intensively mitotically dividing cells (Fig. 2c). Close to the embryo-proper a strong fluorescence of tubulin densities are visible in endosperm (Fig. 2c).

\section{The senescence stage of the suspensor basal cell (>100-celled embryos)}

In the early stage of suspensor basal cell senescence, actin filaments are disorganized. Short, fragmented, and irregularly scattered microfilaments are present in the cytoplasm of the suspensor basal cell (Fig. 3a). There are a number of degraded F-actin filaments, which are concentrated at the micropylar end of a cell (Fig. 3b). Abundant, well-developed actin skeleton is visible in the cells of embryo (Fig. 3a,b). Microtubules are also disorganized and fragmented; disruption of parallel orientation of microtubules in the micropylar part of the suspensor basal cell can be found. Network of microtubules filling the basal cell cytoplasm is loosened (Fig. 3c). An increased cytoplasmic vacuolization is also observed in the suspensor basal cell (Fig. 3a,c).

\section{Discussion}

It is well known that during embryogenesis in the early stages of embryo development, two parts can be distinguished in it: the embryo-proper and suspensor that is a fast-growing, short-living organ being degraded before the development of a mature seed [27]. Suspensors are widespread among angiosperms and they stand out with diverse embryological morphology from other structures. Their presence, however, is not a universal feature, as there are species with embryos devoid of suspensor (Lycopsis, Viola), suspensors can be formed from a single cell (Phaius tankervilliae), several cells (Arabidopsis, Capsella), or a few hundred cells (Phaseolus) [7,28]. Our previous studies indicate that the suspensor in Alisma plantago-aquatica is composed of an enormous suspensor basal cell containing polytene nucleus and several cells of chalazal suspensor $[2,16]$. In many flowering plants, suspensor cell differentiation is accompanied by endoreduplication. It seems that endopolyploid cells are particularly important for tissues and organs that actively function for only a short period of development [29]. Endoreduplication leads to an increased size of the nucleus and multiplication of the genomic DNA quantity, which can significantly affect the increase in RNA transcription and thus accelerate the metabolism of a cell. Probably, endopolyploid cells are better adapted to uptake the nutrients from surrounding tissues [13,30,31]. It is known that cytoplasmic skeleton in plant cells plays an important role during growth and differentiation. So far, the organization of cytoskeletal components has been studied mainly during megasporogenesis and megagametogenesis [32-37]. On the other hand, little information relates to the cytoskeleton during differentiation of highly polyploid cells of embryonic suspensor. In this study, we present fluorescence and immunofluorescence detection of actin and tubulin skeleton in endopolyploid suspensor basal cell in Alisma plantago-aquatica L. At the initial stage of the suspensor development in A. plantago-aquatica, microtubular skeleton forms a delicate network in the cytoplasm of the basal cell, while numerous clusters of actin material are found on the micropylar end of the cell. The presence of such images of actin and tubulin material has been previously reported during the early stages of suspensor differentiation in Phaius tankervilliae [38], Gagea lutea [18], Sedum acre [11], in syncytium in Utricularia [39], or in the endosperm haustorium in Rhinanthus serotinus [40]. In the next, mature, development stage of suspensor in Alisma, actin and tubulin skeleton rebuilds and forms a dense and intricate network of microfilaments and microtubules in the cytoplasm of the basal cell. In our opinion, probably the changes in cytoskeleton organization are associated with the change in shape and enlargement of the basal cell. This has been earlier observed in magnifying suspensor in Phaius tankervilliae [38] or in the growing suspensor basal cell in Sedum acre [11]. In A. plantago-aquatica, the micropylar end of the basal cell, that grows deep into the embryonic tissue, is also characteristically elongated. At the same time, the microfilaments and microtubules density significantly increases at the micropylar end. Probably, the functional importance of cytoskeletal elements density at the micropylar end of the basal cell is related to the transfer nature of the wall. Previous cytochemical and ultrastructural studies revealed the presence of numerous wall ingrowths characteristic for the transfer cells. The presence of transfer walls suggests the possibility of an intensive exchange of nutrients, which occurs between the inner integument and suspensor basal cell, and then their transfer to the developing embryo [2]. Microtubules and microfilaments densities and accompanying numerous mitochondria were also observed in the vicinity of the wall ingrowths in the endosperm in Vicia faba, Zea mays, Triticum aestivum [41], the endosperm-placenta-syncytium in Utricularia [39,42], in endosperm haustorium in Rhinanthus serotinus [40], or in suspensor in Sedum acre [11] and Gagea lutea [18]. It is widely recognized that the presence of transfer walls significantly increases the plasmalemma surface area ensuring more efficient uptake of macromolecules from embryonic tissues $[9,10,43]$. In addition, endopolyploidization occurring in the suspensor basal cell in Alisma may indicate the specialization and high metabolic activity of this cell. It is also possible that both microfilaments and microtubules, besides intracellular transport $[44,45]$, may be also involved in the transfer of intranuclear products to the cytoplasm [46-48]. It seems to be likely, since density of microtubules was observed close to the endopolyploid nucleus of the basal cell in A. plantagoaquatica. Presence of microtubules concentrations in the 


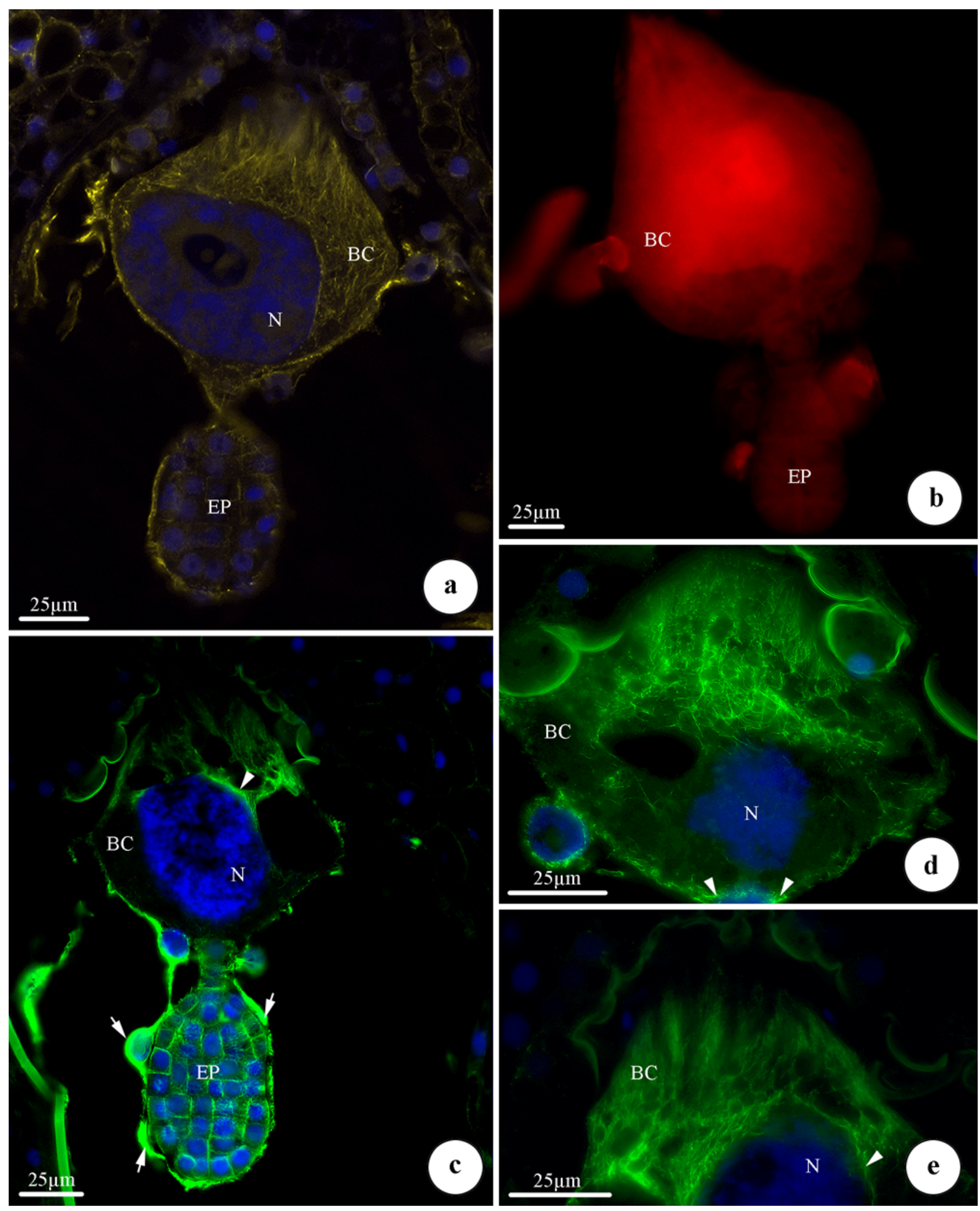

Fig. 2 The mature stage of the suspensor basal cell development of Alisma plantago-aquatica. a Image of immunofluorescence assay of microfilaments. Abundant network of microfilaments in the basal cell. Large amount of actin material occurs at the micropylar end of the cell; enormous polytene nucleus. The microfilament network visible in cells of embryo-proper. $\mathbf{b}$ Image of F-actin visualized by rhodamine-phalloidin. F-actin filaments form a dense network in the suspensor basal cell and cells of embryo-proper. c-e Images of immunofluorescence assay of microtubules. c Numerous microtubules visible in the basal cell cytoplasm, especially at the micropylar end. Intensively glowing microtubule clusters near nucleus (arrow). Intensively fluorescent tubulin skeleton visible in embryo-proper cells. Arrows point to the strong fluorescence of tubulin material present close to the embryo proper. $\mathbf{d}$ Bundles of microfilaments form an intricate network at the micropylar end of the basal cell, the tubulin densities are also visible at the chalazal end of the cell (arrows head). e Fragment of the basal cell, the microtubule network visible at the micropylar end. Microtubule concentrations visible near the nucleus (arrow head). BC - basal cell; E - embryo ; N - nucleus. 


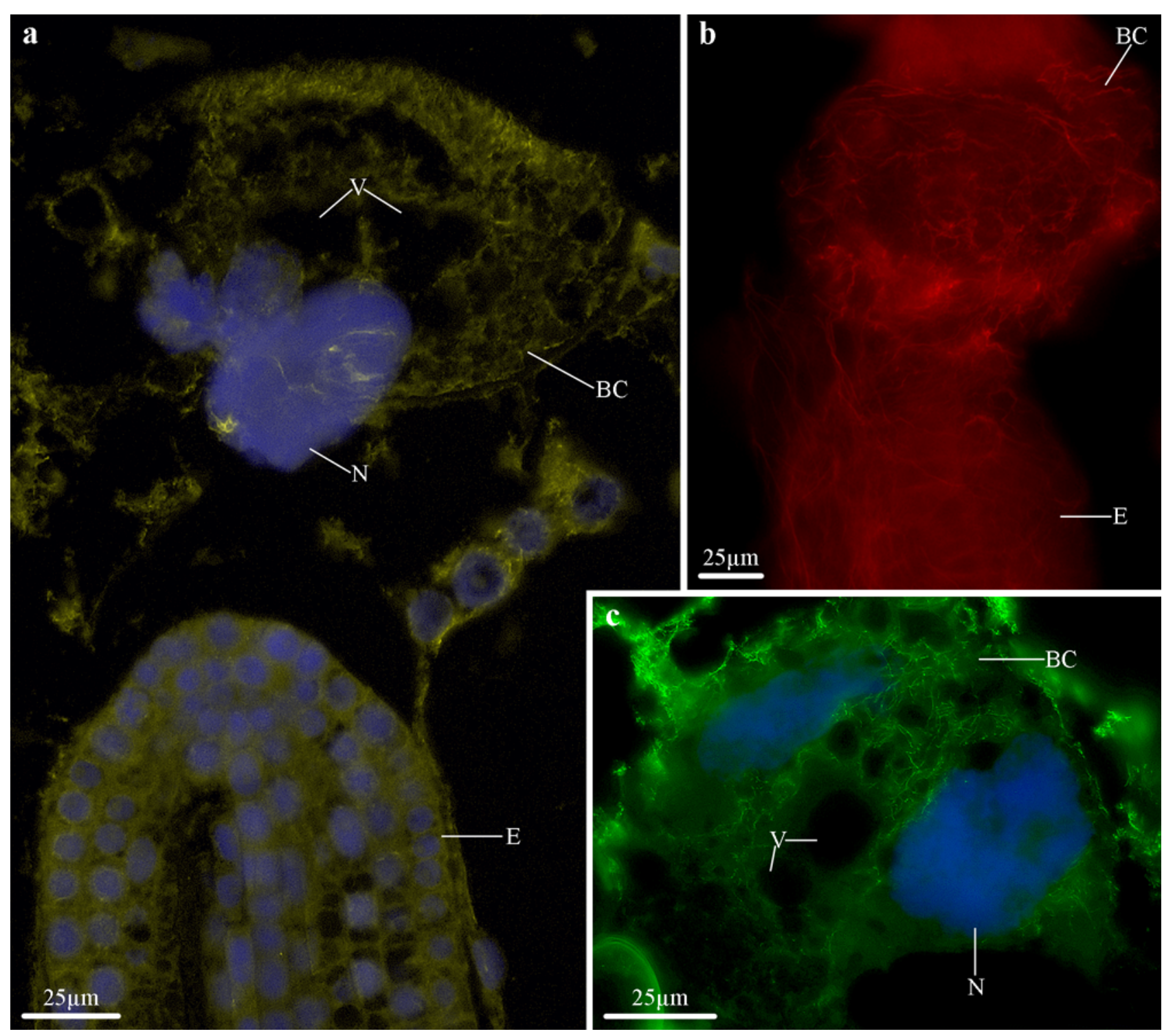

Fig. 3 The aging stage of suspensor development of Alisma plantago-aquatica. a Image of immunofluorescence assay of microfilaments. Short, fragmented, irregularly distributed microfilaments visible in the basal cell cytoplasm; pleated nucleus and numerous vacuoles. b Image of F-actin visualized by rhodamine-phalloidin. Numerous degraded F-actin filaments concentrating at the micropylar end of the basal cell. The microfilament network visible in embryo-proper cells. $\mathbf{c}$ Image of immunofluorescence assay of microtubules. Loosened microtubule network fulfilling the cellular cytoplasm visible in the basal cell; numerous vacuoles. BC - basal cell; E - embryo; $\mathrm{N}$ - nucleus; $\mathrm{V}$ - vacuoles.

vicinity of nuclear envelope was also reported in the chalazal endosperm haustorium and endosperm-placenta syncytia in Utricularia [42], the endosperm haustorium [40], as well as in polyploid cells of the suspensor $[11,18]$. It should not be excluded that microtubules may be involved in the positioning of the huge endopolyploid basal cell nucleus in Alisma. It is very reasonable, because nucleus is centrally located in the young basal cell, while in the old basal cell; nucleus changes its position and moves closer to the chalazal end of a cell. Similar observations were also reported during the differentiation of highly polyploid cell of endosperm haustorium in Rhinanthus serotinus [40]. In the aging suspensor basal cells in Alisma some disturbances in microfilaments and microtubule organization and increased cell vacuolization can be observed. These alterations are correlated with a progressive development of the embryo and endosperm. Probably, basal cell after fulfilling its functions with respect to the embryo begins to degrade; the literature data suggest that this process occurs by means of so-called programmed cell death [49-51]. In conclusion, the presence of abundant actin and tubulin cytoskeleton in endopolyploid suspensor basal cell in Alisma plantago-aquatica is probably associated with the positioning of the nucleus, movement of organelles, and transport of nutrients within the physiologically active cell, which appears to be essential for the proper development of the embryo. 


\section{Acknowledgments}

This study was supported by the grants from the University of Gdańsk (BW 1410-5-0111-7).

\section{Authors' contributions}

The following declarations about authors' contributions to the research have been made: idea of the study: JŚ, JB; immunofluorescence and fluorescence assay: JŚ; microscopical analysis: JŚ, JB; writing of the manuscript: JŚ, JB; photographs: JŚ, JB.

\section{References}

1. Raghavan V. Embryogenesis in Angiosperms. A development and experimental study. Cambrige: Cambrige University Press; 1986.

2. Bohdanowicz J. Alisma embryogenesis: the development and ultrastructure of the suspensor. Protoplasma. 1987;137(2-3):71-83. http:// dx.doi.org/10.1007/BF01281143

3. Kozieradzka-Kiszkurno M, Bohdanowicz J. Development and cytochemistry of the embryo suspensor in Sedum. Acta Biol Cracov Ser Bot. 2006;48(2):67-72.

4. Yeung EC, Clutter ME. Embryogeny of Phaseolus coccineus: the ultrastructure and development of the suspensor. Can J Bot. 1979;57(2):120-136. http://dx.doi.org/10.1139/b79-021

5. Cremonini R, Cionini PG. Extra DNA synthesis in embryo suspensor cells of Phaseolus coccineus. Protoplasma. 1977;91(3):303-313. http:// dx.doi.org/10.1007/BF01281953

6. Singh MB, Bhalla PL, Malik CP. Activity of some hydrolytic enzymes in autolysis of the embryo suspensor in Tropaeolum majus L. Ann Bot. 1980;45(5):523-527.

7. Yeung EC, Meinke DW. Embryogenesis in Angiosperms: development of the suspensor. Plant Cell. 1993;5(10):1371. http://dx.doi. org/10.2307/3869789

8. Schwartz BW, Vernon DM, Meinke DW. Development of the suspensor: differentiation, communication, and programmed cell death during plant embryogenesis. In: Larkins BA, Vasil IK, editors. Cellular and molecular biology of plant seed development. Dordrecht: Springer Netherlands; 1997. p. 53-72. http://dx.doi. org/10.1007/978-94-015-8909-3_2

9. Gunning BES, Pate JS. Transfer cells. In: Robards AW, editor. Dynamic aspects of plant ultrastructure. London: McGraw-Hill; 1974. p. 441-480.

10. Talbot MJ, Offler CE, McCurdy DW. Transfer cell wall architecture: a contribution towards understanding localized wall deposition. Protoplasma. 2002;219(3-4):197-209. http://dx.doi.org/10.1007/ s007090200021

11. Kozieradzka-Kiszkurno M, Świerczyńska J, Bohdanowicz J. Embryogenesis in Sedum acre L.: structural and immunocytochemical aspects of suspensor development. Protoplasma. 2011;248(4):775-784. http:// dx.doi.org/10.1007/s00709-010-0248-z

12. Nagl W. Endopoliploidy and polyteny in differentiation and evolution. Amsterdam: Oxford North-Holland Publishing Company; 1978.

13. D’Amato F. Polyploidy in cell differentiation. Caryologia. 1989;42(3-4): 183-211. http://dx.doi.org/10.1080/00087114.1989.10796966

14. Brady T. Feulgen cytophotometric determination of the DNA content of the embryo proper and suspensor cells of Phaseolus coccineus. Cell Diff. 1973;2(2):65-75. http://dx.doi.org/10.1016/0045-6039(73)90022-5

15. Nagl W. Early embryogenesis in Tropaeolum majus L.: ultrastructure of the embryo-suspensor. Bioch Physiol Pflanz. 1976;170:253-260.

16. Bohdanowicz J. Karyological anatomy of the suspensor in Alisma L. I. Alisma plantago-aquatica L. Acta Biol Cracov Ser Bot. 1973;16:235-248.

17. Świerczyńska J, Bohdanowicz J. The cytoskeleton of the embryosuspensor in Gagea lutea (L.) Ker Gawl. Acta Biol Cracov Ser Bot. 2008;50(1 suppl):73.

18. Świerczyńska J, Bohdanowicz J. The immunocytochemical studies of the embryo-suspensor in Gagea lutea (L.) Ker-Gawl. Acta Biol Crac Ser Bot. 2010;52(1 suppl):41.

19. Świerczyńska J, Bohdanowicz J. The cytoskeleton of the embryosuspensor in Phaseolus coccineus L. Acta Biol Crac Ser Bot. 2012;52(1 suppl):83.
20. Sonobe S, Shibaoka H. Cortical fine actin filaments in higher plant cells visualized by rhodamine-phalloidin after pretreatment with m-maleimidobenzoyl N-hydroxysuccinimide ester. Protoplasma. 1989;148(2-3):80-86. http://dx.doi.org/10.1007/BF02079325

21. Huang BQ, Russell SD. Fertilization in Nicotiana tabacum: cytoskeletal modifications in the embryo sac during synergid degeneration: a hypothesis for short-distance transport of sperm cells prior to gamete fusion. Planta. 1994;194(2):200-214. http://dx.doi.org/10.1007/ BF01101679

22. Traas JA, Doonan JH, Rawlins DJ, Shaw PJ, Watts J, Lloyd CW. An actin network is present in the cytoplasm throughout the cell cycle of carrot cells and associates with the dividing nucleus. J Cell Biol. 1987;105(1):387-395. http://dx.doi.org/10.1083/jcb.105.1.387

23. Świerczyńska J, Bohdanowicz J. Microfilament cytoskeleton of endosperm chalazal haustorium of Rhinanthus serotinus (Scrophulariaceae). Acta Biol Crac Ser Bot. 2003;45(1):143-148.

24. Bohdanowicz J, Szczuka E, Świerczyńska J, Sobieska J, Kościńska-Pająk M. The distribution of microtubules during regular and disturbed microsporogenesis and pollen grain development in Gagea lutea (L.) Ker.-Gaw. Acta Biol Crac Ser Bot. 2005;47:89-96.

25. Brown RC, Lemmon BE, Mullinax JB. Immunofluorescent staining of microtubules in plant tissues: improved embedding and sectioning techniques using polyethylene glycol (PEG) and Steedman's wax. Bot Acta. 1989;102(1):54-61. http://dx.doi.org/10.1111/j.1438-8677.1989. tb00067.x

26. Vitha S, Baluška F, Jasik J, Volkmann D, Barlow PW. Steedman's wax for F-actin visualization. In: Staiger CJ, Baluška F, Volkmann D, Barlow PW, editors. Actin: a dynamic framework for multiple plant cell functions. Dordrecht: Springer Netherlands; 2000. p. 619-636. http://dx.doi.org/10.1007/978-94-015-9460-8_35

27. Maheshwari P. An introduction to the embryology of angiosperms. New York, NY: McGrraw-Hill; 1950.

28. Kozieradzka-Kiszkurno M, Płachno BJ, Bohdanowicz J. New data about the suspensor of succulent angiosperms: ultrastructure and cytochemical study of the embryo-suspensor of Sempervivum arachnoideum L. and Jovibarba sobolifera (Sims) Opiz. Protoplasma. 2012;249(3):613-624. http://dx.doi.org/10.1007/s00709-011-0297-y

29. Brodsky VY, Uryvaeva IV. Genome multiplication in growth and development. Biology of polyploid and polytene cells. London: Cambridge University Press; 1985.

30. Nagl W. Polyploidy in differentiation and evolution. Inter J Cell Clon. 1990;8(4):216-223. http://dx.doi.org/10.1002/stem.5530080404

31. Joubès J, Chevalier C. Endoreduplication in higher plants. Plant Mol Biol. 2000;43(5-6):735-745. http://dx.doi. org/10.1023/A:1006446417196

32. Willemse MTM, van Lammeren AAM. Structure and function of the microtubular cytoskeleton during megasporogenesis and embryo sac development in Gasteria verrucosa (Mill.) H. Duval. Sex Plant Reprod. 1988;82:631-634.

33. Bednara J, Willemse MTM, van Lammeren AAM. Organization of the actin cytoskeleton during megasporogenesis in Gasteria verru$\cos a$ visualized with fluorescent-labelled phalloidin. Acta Bot Neerl. 1990;39:43-48.

34. Zee SY, Ye XL. Changes in the pattern of organization of the microtubular cytoskeleton during megasporogenesis in Cymbidium sinense. Protoplasma. 1995;185(3-4):170-177. http://dx.doi.org/10.1007/ BF01272857

35. Huang BQ, Ye. XL, Yeung E, Zee SY. Embryology of Cymbidium sinense: the microtubule organization of early embryos. Ann Bot. 1998;81(6):741-750. http://dx.doi.org/10.1006/anbo.1998.0628

36. Tung SH, Ye XL, Yeung EC, Zee SY. Ultrastructural aspects of megasporogenesis in Cymbidium sinensie (Orchidaceae). Lindleyana. 1999;14:178-192.

37. Tung SH, Ye XL, Zee SY, Yeung EC. The microtubular cytoskeleton during megasporogenesis in the nun orchid, Phaius tankervillae. New Phytol. 2000;146(3):503-513. http://dx.doi. org/10.1046/j.1469-8137.2000.00656.x

38. Ye XL, Zee SY, Yeung EC. Suspensor development in the nun orchid Phaius tankervilliae. Inter J Plant Sci. 1997;162:1053-1063. 
39. Płachno BJ, Światek P, Kozieradzka-Kiszkurno M. The F-actin cytoskeleton in syncytia from non-clonal progenitor cells. Protoplasma. 2011;248(3):623-629. http://dx.doi.org/10.1007/s00709-010-0209-6

40. Świerczyńska J, Kozieradzka-Kiszkurno M, Bohdanowicz J. Rhinanthus serotinus (Schönheit) Oborny (Scrophulariaceae): immunohistochemical and ultrastructural studies of endosperm chalazal haustorium development. Protoplasma. 2013;250(6):1369-1380. http://dx.doi. org/10.1007/s00709-013-0520-0

41. Thompson RD, Hueros G, Becker HA, Maitz M. Development and functions of seed transfer cells. Plant Sci. 2001;160(5):775-783. http:// dx.doi.org/10.1016/S0168-9452(01)00345-4

42. Płachno BJ, Świątek P, Sas-Nowosielska H, Kozieradzka-Kiszkurno M. Organisation of the endosperm and endosperm-placenta syncytia in bladderworts (Utricularia, Lentibulariaceae) with emphasis on the microtubule arrangement. Protoplasma. 2013;250(4):863-873. http:// dx.doi.org/10.1007/s00709-012-0468-5

43. Offler CE, McCurdy DW, Patrick JW, Talbot MJ. Transfer cells: cells specialized for a special purpose. Ann Rev Plant Biol. 2003;54(1):431454. http://dx.doi.org/10.1146/annurev.arplant.54.031902.134812

44. Kamal A, Goldstein LSB. Connecting vesicle transport to the cytoskeleton. Curr Opin Cell Biol. 2000;12(4):503-508. http://dx.doi. org/10.1016/S0955-0674(00)00123-X

45. Verchot-Lubicz J, Goldstein RE. Cytoplasmic streaming enables the distribution of molecules and vesicles in large plant cells. Protoplasma. 2010;240(1-4):99-107. http://dx.doi.org/10.1007/s00709-009-0088-x

46. Muench DG, Park NI. Messages on the move: the role of the cytoskeleton in mRNA localization and translation in plant cells. Can J Bot. 2006;84(4):572-580. http://dx.doi.org/10.1139/b05-167

47. Guo F, Yu L, Watkins S, Han Y. Orientation of microtubules suggests a role in mRNA transportation in fertilized eggs of Chinese pine (Pinus tabulaeformis). Protoplasma. 2007;231(3-4):239-243. http://dx.doi. org/10.1007/s00709-007-0266-7

48. Zarnack K, Feldbrugge M. Microtubule-dependent mRNA transport in fungi. Eukaryot Cell. 2010;9(7):982-990. http://dx.doi.org/10.1128/ EC.00030-10

49. Giuliani C, Consonni G, Gavazzi G, Colombo M, Dolfini S. Programmed cell death during embryogenesis in maize. Ann Bot. 2002;90(2):287-292. http://dx.doi.org/10.1093/aob/mcf173

50. Bozhkov PV, Filonova LH, Suarez MF. Programmed cell death in plant embryogenesis. Curr Top Dev Biol. 2005;67:135-179. http://dx.doi. org/10.1016/S0070-2153(05)67004-4

51. Lombardi L, Ceccarelli N, Picciarelli P, Lorenzi R. DNA degradation during programmed cell death in Phaseolus coccineus suspensor. Plant Physiol Biochem. 2007;45(3-4):221-227. http://dx.doi.org/10.1016/j. plaphy.2007.01.014 